\title{
STUDI KONDISI KESEHATAN LINGKUNGAN RSUD PROF. DR. MARGONO SOEKARJO PURWOKERTO TAHUN 2016
}

\author{
Risma Suryani Prasetyaningsih"1), Yulianto ${ }^{2)}$ \\ Jurusan Kesehatan Lingkungan, Politeknik Kesehatan Kemenkes Semarang, \\ Jl.Raya Baturaden KM 12 Purwokerto, Indonesia
}

\begin{abstract}
Abstrak
Rumah sakit merupakan fasilitas pelayanan kesehatan sebagai upaya untuk memelihara dan meningkatkan kesehatan masyarakat, jika rumah sakit tidak dikelola dengan baik akan memberikan dampak negatif dari rumah sakit terhadap kesehatan pasien, pengunjung dan masyarakat. Tujuan penelitian ini adalah mendeskripsikan kondisi kesehatan lingkungan rumah sakit yang meliputi kesehatan lingkungan rumah sakit, penyehatan ruang bangunan, penyehatan makanan dan minuman, penyehatan air, pengelolaan limbah, tempat pencucian linen, pengendalian serangga dan tikus, dekontaminasi melalui desinfeksi dan sterilisasi, pengamanan radiasi, penyuluhan kesehatan lingkungan, dan unit/instalasi sanitasi rumah sakit. Hasil penelitian kondisi kesehatan lingkungan RSUDProf Dr Margono Soekarjo Purwokerto yaitu kondisi kesehatan lingkungan rumah sakit 96,8\% (memenuhi syarat), penyehatan ruang bangunan 88,4\% (memenuhi syarat), penyehatan makanan dan minuman 90,7\% (memenuhi syarat), penyehatan air 88,1\% (memenuhi syarat), pengelolaan limbah 84,4\% (memenuhi syarat), tempat pencucian linen $100 \%$ (memenuhi syarat), pengendalian serangga dan tikus $100 \%$ (memenuhi syarat), dekontaminasi melalui desinfeksi dan sterilisasi 100\% (memenuhi syarat), pengamanan radiasi 75\% (tidak memenuhi syarat), penyuluhan kesehatan lingkungan 100\% (memenuhi syarat), dan unit/instalasi sanitasi rumah sakit 100\% (memenuhi syarat). Berdasarkan hasil penelitian dapat dikatakan bahwa kondisi kesehatan lingkungan RSUD Prof Dr Margono Soekarjo Purwokerto mendapatkan skor 93,2\% dan dikatakan memenuhi syarat, hanya saja terdapat satu variabel yang tidak memenuhi syarat yaitu pada variabel IX mengenai pengamanan radiasi, disarankan kepada pihak rumah saki dan bagian iplrs untuk lebih memperhatikan dampak yang ditimbulkan dengan cara melakukan pengadaan pelapisan timah hitam pada dinding dan daun pintu di ruang radiologi.
\end{abstract}

Kata kunci $\quad$ : Kesehatan Lingkungan Rumah Sakit

\begin{abstract}
[Study of hospital environmental health condition RSUD Prof. Dr. Margono Soekarjo Purwokerto 2016]. Hospitals are health care fasiities in an effort to maintain and improve public health, if the hospital is not managed properly will have a negative impact patients, visitors, staff and public. The purpose of this study to describe the health condition of the hospital environment involve health of hospital environmental, restructuring building space, restructuring of food and drinks, sanitation water, waste management, washes linen, controlling insects and rodents, decontamination through disinfection and sterilization, security radiation, environmental health, and unit/hospital sanitary installations. The result of this research are healths of hospital environment 96,8\% (quality), restructuring of the building space 88,4\% (quality), restructuring of food and beverage 90,7\% (qulity), water sanititation 88,1\% (quality), waste management 84,4\% (quality), washing linen 100\% (quality), controlling insects and rodents $80 \%$ (quality), decontamination through disinfection and sterilization $100 \%$ (quality), safeguarding radiation 75\% (not eligible), environmental health education 100\% (quality, unit/hospital sanitaryinstallations 100\% (quality). Based on the results of this study concluded that the health condition of the Prof Dr Margono Soekarjo hospital Purwokerto gets score 93,2\% and quality, but one variable does not quality, specially variable IX on radiation security, the hospital and part IPSRS suggested to pay more attention to the impact by conducting procurement lead coating on the walls and doors in the radiology room.
\end{abstract}

Keywords : : Hospital Environmental Health

\section{PENDAHULUAN}

Rumah sakit adalah institusi pelayanan kesehatan yang menyelenggarakan pelayanan kesehatan perorangan secara paripurna yang menyediakan pelayanan rawat inap, rawat jalan, dan gawat darurat. Rumah sakit umum adalah rumah sakit yang memberikan pelayanan kesehatan pada semua bidang

1) Email : rismasuryani@yahoo.com

2) Email : yulianto_61@yahoo.com dan jenis penyakit. (Permenkes RI No. 340/MENKES/PER/III/2010)

Rumah sakit yang tidak dikelola dengan baik akan memberikan dampak negatif dari rumah sakit terhadap kesehatan pasien, pengunjung, petugas kesehatan masyarakat sekitar yang menimbulkan penyakit infeksi nosokomial dan memungkinkan 
terjadinya pencemaran lingkungan apabila dalam pengelolaannya tidak memperhatikan persyaratan kesehatan lingkungan sesuai Keputusan Menteri Kesehatan RI Nomor 1204/MENKES/SK/X/2004 tentang Persyaratan Kesehatan Lingkungan Rumah Sakit sebagai pendukung usaha penyembuhan penderita disamping mencegah terjadinya penularan infeksi nosokomial kepada orang sehat baik petugas rumah sakit, pengunjung maupun masyarakat di sekitar rumah sakit

Berbagai upaya sanitasi rumah sakit adalah kesehatan lingkungan rumah sakit, penyehatan ruang bangunan, penyehataan makanan dan minuman, penyehatan air, pengelolaan limbah, tempat pencucian linen (laundry), pengendalian serangga dan tikus, dekontaminasi melalui desinfeksi dan sterilisasi, pengamanan radiasi, penyuluhan kesehatan lingkungan dan unit/instalasi sanitasi rumah sakit.

Berdasarkan hasil penelitian sebelumnya yang dilakukan oleh Rifki Ridho tahun 2011 didapatkan hasil yaitu pengelolaan sampah non medis sudah berjalan dengan baik pada tahap penimbulan sampah yang dihasilkan rata-rata setiap hari 2.531, $5 \mathrm{~kg}$ dan volume 19.951,9 L, tetapi pada tahap ini masih ada tercampurnya sampah non medis dengan sampah medis dan tidak adanya proses pengolahan/ pemanfaatan kembali sampah non medis dan berdasarkan hasil penelitian yang dilakukan Ayu Dwi Arini Putri tahun 2012 didapatkan hasil yaitu ratarata angka kuman udara sebelum desinfeksi 69 $\mathrm{CFU} / \mathrm{m}^{3}$, sesudah desinfeksi $11 \mathrm{CFU} / \mathrm{m}^{3}$.

Tujuan dalam penelitian ini yaitu mendeskrpsikan kondisi kesehatan lingkungan RSUD Prof. Dr. Margono Soekarjo Purwokerto Tahun 2016.

\section{BAHAN DAN METODE}

Jenis penelitian ini merupakan penelitian deskriptif dengan jenis deskriptif evaluatif untuk memperoleh gambaran tentang sistem pengelolaan kesehatan lingkungan rumah sakit di RSUD Prof. Dr. Margono Soekarjo Purwokerto.

Subjek penelitian yaitu lingkungan RSUD Prof. Dr. Margono Soekarjo Purwokerto dengan acuan menggunakan inspeksi sanitasi rumah sakit menurut Kepmenkes RI Nomor 1204/MENKES/SK/X/2004.

Data diperloleh dengan cara observasi, wawancara dan dokumentasi. Instrument yang digunakan berupa checklist dan kuesioner dengan menggunakan pedoman Kepmenkes RI Nomor 1204/MENKES/SK/X/2004.

Analisis data dilakukan adalah analisis deskriptif, yaitu dengan mendeskripsikan kondisi kesehatan lingkungan rumah sakit, penyehatan ruang bangunan rumah sakit, penyehatan makanan dan minuman, penyehatan air, pengelolaan limbah, pencucian linen (laundry), pengendalian serangga dan tikus, dekontaminasi melalui desinfeksi dan sterilisasi, pengamanan radiasi, penyuluhan kesehatan lingkungan, dan unit/instalasi sanitasi rumah sakit. Demikian pula dengan hasil yang didapatkan dibandingkan dengan teori yang ada pada pedoman atau standar KepMenkes RI Nomor 1204/MENKES/SK/X/2004 tentang Persyaratan Kesehatan Lingkungan Rumah Sakit.

\section{HASIL DAN PEMBAHASAN}

\section{Gambaran Umum RSUD Prof. Dr. Margono Soekarjo Purwokerto \\ RSUD Prof. Dr. Margono Soekarjo Purwokerto} merupakan salah satu rumah sakit yang berada di wilayah karisidenan Banyumas. Dahulu bernama Rumah Sakit Umum (RSU) Purwokerto yang terletak di belakang kantor bupati Purwokerto, tepatnya di Jalan Dr. Angka No.2. Awalnya rumah sakit ini dibangun oleh pemerintah Hindia Belanda atau yang lebih dikenal dengan nama RS Zending, untuk memberikan pelayanan kesehatan bagi orang Belanda dan misioanaris yang ada di Purwokerto dan sekitarnya.

Nama RSUD Prof. Dr. Margono Soekarjo Purwokerto diambil dari nama seorang dokter ahli bedah pertama di Indonesia yang sangat berjasa di dunia kedokteran, yang berasal dari Purwokerto. Berdasarkan surat keputusan DPRD Dati II Banyumas pada tanggal 3 September 1981 No. 3/5/V/DPRD/1981. Nama RSU Purwokerto diganti menjadi Prof. Dr. Margono Soekarjo Purwokerto. Sebelumnya RSUD Prof. Dr. Margono Soekarjo Purwokerto merupakan RSU tipe C yang kemudian meningkat menjadi tipe $\mathrm{B}$ pendidikan bersama dengan dikeluarkannya SK Menkes RI No. 41/Menkes/SK/I/1987, tanggal 21 Januari tentang peningkatan RSU Purwokerto tipe C menjadi tipe B pendidikan, kemudian dengan ditindak lanjuti dengan SK Gubernur Kepala Daerah Tingkat Jawa Tengah No. 016/091/1988 tangal 5 Mei 1988 maka secara resmi RSU Purwokerto berubah menjadi tipe B.

\section{Gambaran Khusus RSUD Prof. Dr. Margono} Soekarjo Purwokerto

1. Kesehatan Lingkungan RSUD Prof. Dr Margono Soekarjo Purwokerto

a. Lantai

Lantai yang ada di RSUD Prof. Dr Margono Soekarjo Purwokerto menggunakan lantai dari keramik, memiliki konstruksi kuat dan utuh, kondisi bersih, kedap air, tidak licin dan permukaan lantai rata, mudah dibersihkan dan pertemuan lantai dan dinding berbentuk konus atau lengkung. Akan tetapi masih ada bangunan dan ruangan yang pertemuan lantai dengan dindingnya tidak berbentuk konus dan dengan kondisi kurang bersih dan sedikit sulit dibersihkan, untuk itu pertemuan antara lantai dan dinding harus berbentuk konus atau lengkung agar mudah dibersihkan pada saat pembersihan lantai, dan debu tidak 
terselip disela lantai sehingga lantai mudah dibersihkan serta terlihat bersih.

\section{b. Dinding}

Dinding bangunan dan ruangan di RSUD Prof. Dr Margono Soekarjo Purwokerto dalam keadaan rata, bersih, berwarna terang, mudah dibersihkan, dan menggunakan cat yang tidak mudah luntur, untuk itu kondisi ini harus dipertahankan dan lebih ditingkatkan agar tetap dalam kondisi baik dengan pembersihan rutin dinding rumah sakit dan apabila cat sudah berwarna kusam sebaiknya dicat ulang.

\section{c. Ventilasi}

RSUD Prof. Dr Margono Soekarjo Purwokerto menggunakan ventilasi alam dan ventilasi mekanis. Sebagian besar ventilasi ruangan di RSUD Prof. Dr Margono Soekarjo Purwokerto menggunakan ventilasi mekanis, seperti pada ruang rawat inap kelas I dan kelas II namun untuk kelas II ada sebagian ruangan tidak menyalakan AC dikarenakan perbedaan kebiasaan pasien yang tidak menggunakan AC, untuk ruangan yang menggunakan ventilasi alam, lubang penghawaannya sudah menjamin aliran udara di ruang dengan baik sehingga di dalam ruangan yang menggunakan ventilasi alam tidak merasakan pengap dan sebagian besar luas ventilasi $15 \%$ dari luas lantai. untuk itu kondisi ini harus dipertahankan dan lebih ditingkatkan agar tetap dalam kondisi baik dengan selalu membuka jendela agar ruangan tidak pengap.

\section{d. Atap}

RSUD Prof. Dr Margono Soekarjo Purwokerto menggunakan atap dari genteng yang bebas dari serangga dan tikus, tidak bocor, berwarna terang dan mudah dibersihkan, untuk itu kondisi ini harus dipertahankan dan lebih ditingkatkan agar tetap dalam kondisi baik dengan membersihkan rutin atap rumah sakit.

\section{e. Langit-langit}

Langit-langit pada sebagian besar ruangan yang ada di RSUD Prof. Dr Margono Soekarjo Purwokerto menggunakan eternit berwarna terang, kuat, mudah dibersihkan dan dengan ketinggian 3 meter dari lantai, kecuali pada gudang yang tidak terdapat langit-langit sehingga sulit dibersihkan dan terlihat kotor, pada gudang yang tidak memiliki langit-langit sebaiknya dilakukan perbaikan bangunan dengan memberikan eternit atau ditutup menggunakan papan agar terlihat rapi dan bersih sehingga mudah dibersihkan.

f. Konstruksi Balkon, Beranda dan Talang
Tidak ada genangan air, tidak ada jentik sehingga tidak menjadi tempat perindukan nyamuk dan mudah dibersihkan, untuk itu kondisi ini harus dipertahankan dan lebih ditingkatkan agar tetap dalam kondisi baik dengan pembersihan rutin.

g. Pintu

RSUD Prof. Dr Margono Soekarjo Purwokerto menggunakan pintu yang kuat sehingga dapat mencegah masuknya serangga dan tikus dan binatang pengganggu lainnya. Apabila ada bagian pintu yang rusak maka sebaiknya dilakukan perbaikan bila memungkinkan atau dilakukan pergantian jika pintu sudah benar-benar tidak dapat digunakan.

h. Pagar

RSUD Prof. Dr Margono Soekarjo Purwokerto dikelilingi oleh pagar yang berbahan besi, kuat dan aman. Pada jalan masuk bagian belakang gedung RSUD Prof. Dr Margono Soekarjo Purwokerto dilengkapi pagar keliling yang setiap pukul 07.30 dibuka untuk keluar masuknya transportasi sampah di TPS, sebaiknya kondisi ini tetap dipertahankan dan lebih ditingkatkan agar tetap dalam kondisi baik.

\section{i. Halaman taman dan Tempat Parkir}

Halaman dan tempat parkir selalu nampak bersih, namun jika musim hujan becek dan berdebu, disediakan tempat sampah yang cukup. Untuk tempat parkir mampu menampung kendaraan karyawan dan pengunjung. Tempat parkir terpisah antara roda 2 dan roda 4 dan memiliki ramburambu lalu lintas yang jelas, untuk halaman dan tempat parkir sebaiknya dilakukan perbaikan karena jika pada musim hujan selalu becek dan berdebu hal ini dapat mengganggu kenyamanan karyawan maupun pengunjung.

j. Jaringan instalasi

Jaringan instalasi di RSUD Prof. Dr Margono Soekarjo Purwokerto aman (bebas cross connection) dan terlindungi, untuk menjaga agar tetap dalam kondisi baik untuk itu selalu dilakukan pemeliharaan dan pemantauan jaringan instalasi agar terhindar dari kerusakan.

\section{k. Saluran air limbah}

Air limbah yang berasal dari sumbernya masing-masing disalurkan ke IPAL dengan pipa yang tertutup sehingga tidak menimbulkan bau dan aliran air lancar. untuk itu selalu dilakukan pemeliharaan dan pemantauan sarana air limbah agar terhindar dari kerusakan.

\section{Ruang Bangunan}

\section{a. Ruang perawatan}


Ruang rawat inap kelas I memiliki 2 tempat tidur dan 1 kamar mandi dan toilet dalam dengan luas $\pm 11 \mathrm{~m} 2$. Ruang rawat inap untuk anak atau bayi dalam 1 ruangan ada 2 tempat tidur dan 1 kamar mandi dengan luas ruangan $5 \mathrm{~m} 2$. Angka kuman udara di ruang perawatan masih dibawah batas maksimal, ruang perawatan terbebas dari serangga dan tikus. Kualitas udara ruang tidak berdebu (terutama bebas dari H2S dan NH3). Pencahayaan ruang perawatan pada bulan maret-april sebagian besar masih tidak memenuhi syarat (>200 lux) tetapi pada bulan mei pencahayaan di ruang perawatan sebagian besar sudah memenuhi syarat ( $<200$ lux), suhu di ruang perawatan yaitu kisaran 29-310 C (AC tidak dinyalakan), kelembaban ruangan pada bulan maret-april kisaran $60-70 \%$ (AC tidak dinyalakan) tetapi pada bulan mei beberapa ruangan dengan kelembaban 45 -60\% (AC dinyalakan ) dan untuk kelembaban $>60 \%$ (AC tidak dinyalakan), untuk tingkat kebisingan di ruang perawatan sebagian besar tidak memenuhi syarat (45 dBA).

Berdasarkan hasil wawancara dengan petugas kebersihan RSUD Prof. Dr Margono Soekarjo Purwokerto bahwa pembersihan di dalam ruang rawat dilakukan pada pagi hari saja sedangkan untuk luar ruangan dibersihkan pada pagi, siang dan sore hari. Setiap ruang rawat inap sudah disediakan perlengkapan kebersihan sendiri, Tidak dilakukan pemeriksaan kadar debu maksimal karena tidak tersedia alat yang memadai dan petugas yang mampu melaksanakan pemeriksaan, sebaiknya bekerja sama dengan instansi atau pihak lain untuk melaksanakan pemeriksaan.

\section{b. Lingkungan RS}

Lingkungan rumah sakit dibagi menjadi 2 yaitu lingkungan bagian dalam dan bagian luar. Untuk lingkungan bagian dalam atau ruangan sebagian besar menggunakan AC atau ventilasi mekanis sehingga merokok sangat dilarang sedangkan bagian luar sudah ada larangan untuk tidak merokok tapi kenyataan ada beberapa keluarga pasien atau pengunjung masih merokok dikawasan rumah sakit. Intensitas cahaya di lingkungan rumah sakit sudah cukup baik. Saluran air limbah tertutup, tetapi saluran drainase sedikit lambat dan tidak mengalir lancar. Saluran air limbah tertutup, tetapi saluran drainase sedikit lambat dan tidak mengalir lancar hal tersebut disebabkan karena ada sampah yang menyangkut, sebaiknya dilakukan pembersihan secara rutin dan diberi peringatan yang lebih untuk tidak membuang sampah sembarangan.

\section{c. Ruang operasi}

Dinding menggunakan porselin, pintu selalu tertutup, langit-langit tidak bercelah dengan ketinggian $3 \mathrm{~m}$ dari lantai, sirkulasi udara menggunakan AC yang sudah dilengkapi filter bakteri, bebas kuman patogen, terdapat 16 kamar operasi dengan suhu ruang yang memenuhi syarat yaitu kisaran $19-25^{\circ} \mathrm{C}$. Pencahayaan ruang tanpa lampu 237 lux sedangkan dengan lampu 438 lux, pencahayaan meja operasi sebagian besar tidak memenuhi syarat yaitu >20.000 lux, hal ini dimungkinkan dari lampu dengan watt yang besar, untuk itu watt lampu di meja operasi sebaiknya dikurangi dengan cara mengganti lampu yang ukuran watt lebih kecil.

\section{d. Ruang laboratorium}

Dinding pada ruang laboratorium terbuat dari keramik dengan tinggi 1,5 m dari lantai sedangkan sisa dinding lainnya dicat dengan warna terang, lantai dan meja tahan terhadap bahan kimia dan getaran, ruang laboratorium dilengkapi dengan dapur, kamar mandi dan toilet, langit-langit berwarna terang dan kokoh dengan ketinggian 3 meter dari lantai. Hasil pemeriksaan tingkat kebisingan yaitu 46,45 dBA, untuk itu kondisi ini harus tetap dipertahankan dan lebih ditingkatkan agar kondisi ini selalu dalam keadaan baik.

\section{e. Ruang sterilisas}

Pada ruang sterilisasi pintu dibuat terpisah antara jalan masuk dengan jalan keluar dan tersedia ruangan khusus. Ruangan khusus digunakan untuk penyimpanan alat-alat yang sudah disterilkan dan disediakan rak-rak kaca untuk penyimpanan sebelum alat didistribusikan. Dinding terbuat dari keramik dengan ketinggian 1,5 m dari lantai, untuk itu kondisi ini harus tetap dipertahankan dan lebih ditingkatkan agar kondisi ini selalu dalam keadaan baik.

\section{f. Ruang Radiologi}

Dinding, daun pintu dan kaca jendela tidak terbuat dari bahan timah hitam, tinggi langitlangit 3,3 m dari lantai. Terdapat peraturan khusus untuk larangan bagi pengunjung agar tidak memasuki ruangan kecuali karyawan, untuk itu perlu dilakukan perbaikan bangunan pada bagian dinding dan daun pintu dengan melapisi bahan timah hitam.

\section{g. Ruang pendingin}

Ruang pendingin terletak di instalasi gizi dengan pintu besi yang suhu ruangnya sudah diatur dalam kisaran -100 C sampai dengan $50 \mathrm{C}$ dan dilengkapi rak makanan dengan tinggi $25 \mathrm{~cm}$ dari lantai.

\section{h. Ruang mayat}


Dinding pada ruang mayat dilapisi keramik, dilengkapi dengan saluran pembuangan air limbah dari hasil pemilisan dan pemandian jenazah serta toilet, dilengkapi dengan ruang ganti pakaian petugas, dilengkapi perlengkapan dari bahan pemilisan dan pemandian jenazah. Letak ruang mayat jauh dari bagian pathologi atau laboratorium, ruang pemeriksaan, ruang perawatan, UGD, dan ruang operasi, sebaiknya selalu mempertahankan dan lebih ditingkatkan agar kondisi ini tetap baik.

\section{i. Toilet dan kamar mandi}

Disediakan 1 kamar mandi untuk 1-2 tempat tidur pada ruang rawat inap, tersedia toilet pada setiap unit atau ruang khusus untuk ruang inap dan karyawan. Khusus ruang operasi kamar mandi dan toilet letaknya tidak berhubungan langsung dengan dapur, kamar operasi. Semua kamar mandi dan toilet dilengkapi dengan saluran air limbah dan lubang penghawaan atau ventilasi yang langsung berhubungan dengan udara luar, tersedia kamar mandi dan toilet untuk pria dan wanita dan karyawan terpisah, sebaiknya kondisi ini tetap dipertahankan dan lebih ditingkatkan agar tetap dalam kondisi baik.

\section{Penyehatan makanan dan minuman}

\section{a. Bahan makanan dan makanan jadi}

Kondisi bahan makanan dan makanan jadi secara fisik sudah memenuhi syarat, untuk sayuran, ikan, daging dan buah masih dalam keadaan segar. Kondisi bahan makanan dan makanan jadi secara bakteriologis memenuhi syarat. sebaiknya kondisi ini tetap dipertahankan dan lebih ditingkatkan agar tetap dalam kondisi baik.

b. Tempat penyimpanan bahan makanan dan makanan jadi

Penyimpanan bahan makanan terpisah antara makanan yang mudah membusuk atau bahan makanan basah dengan bahan makanan yang tidak mudah membusuk. Untuk penyimpanan bahan makanan dan makanan jadi disimpan terpisah, makanan tidak pernah disimpan untuk disajikan lebih dari 6 jam. Tempat penyimpanan bahan makanan dan makanan jadi dalam keadaan bersih, terlindung dari debu, bebas gangguan serangga dan tikus, sebaiknya kondisi ini tetap dipertahankan dan lebih ditingkatkan agar tetap dalam kondisi baik.

\section{c. Penyajian makanan}

Penyajian makanan menggunakan kereta dorong tertutup, tidak menyajikan makanan jadi yang sudah menginap, tetapi untuk lalu lintas makanan jadi tidak menggunakan jalur khusus, sebaiknya untuk lalu lintas makanan jadi menggunakan jalur khusus apabila tidak terdapat jalur khusus hal ini dapat memungkinkan terjadinya kontaminasi dari sumber lain.

d. Tempat pengolahan makanan (dapur)

Lantai dapur sebelum dan sesudah kegiatan selalu dibersihkan dengan antiseptik. Tempat pengolahan dilengkapi dengan sungkup dan cerobong asap.

Pencahayaan di tempat pengolahan makanan (dapur) yaitu 188 lux dikatakan memenuhi syarat dan kondisi ini harus tetap dipertahankan dan lebih ditingkatkan agar tetap dalam kondisi baik.

e. Penjamah makanan

Penjamah makanan memiliki surat keterangan sehat yang berlaku, penjamah makanan tidak berkuku panjang, koreng, menggunakan pakaian pelindung pengolahan makanan, selalu menggunakan peralatan dalam menjamah makanan jadi dan berperilaku sehat selama bekerja, sebaiknya kondisi ini tetap dipertahankan dan lebih ditingkatkan agar tetap dalam kondisi baik.

\section{f. Peralatan}

Sebelum digunakan peralatan selalu dalam kondisi bersih, tahan karat dan tidak mengandung bahan beracun, utuh, tidak retak. Peralatan dicuci lalu dikeringkan dengan pemanas buatan dan tidak dibersihkan dengan kain, sebaiknya kondisi ini tetap dipertahankan dan lebih ditingkatkan agar tetap dalam kondisi baik.

\section{Penyehatan air}

\section{a. Kuantitas}

Sumber air bersih di RSUD Prof. Dr. Margono Soekarjo berasal dari sumur pompa dalam (Deepth Well). Terdapat tiga sumur sebagai sumber air bersih di RSUD Prof. Dr Margono Soekarjo Purwokerto yaitu di taman Soepardjo Roestam dengan kedalaman $80 \mathrm{~m}$, kemudian belakang pengolahan air bersih dengan kedalaman 25 m (tetapi sudah tidak digunakan lagi), dan di belakang IPS dengan kedalaman $100 \mathrm{~m}$. Bak reservoir 1 mempunyai panjang 4m, lebar 4 $\mathrm{m}$, dengan kedalaman $5 \mathrm{~m}$. Bak ini dialirkan dengan pompa otomatis ke seluruh wastafel, ICPH, Gizi, Laboratorium, ICU, dan IBS. Bak Reservoir 2 mempunyai panjang 12m, lebar $6 \mathrm{~m}$, dengan kedalaman $5 \mathrm{~m}$. Tersedia air bersih $600 \mathrm{lt} / \mathrm{tt} / \mathrm{hari}$ dan tersedia air minum sesuai dengan kebutuhan dan tersedia pada setiap tempat kegiatan, untuk itu kondisi ini harus tetap dipertahankan dan lebih ditingkatkan agar tetap dalam kondisi baik.

\section{b. Kualitas}


Secara kualitas air bersih diperiksa secara bakteriologis, kimia dan fisika, sebaiknya kondisi ini tetap dipertahankan dan lebih ditingkatkan agar tetap dalam kondisi baik.

c. Sarana

Tidak menggunakan air yang berasal dari PDAM, distribusi tidak bocor, penampungan air tertutup dan terlindungi, sebaiknya dilakukan pemantauan dan pemeliharaan untuk sarana agar distribusi tidak bocor.

\section{Pengelolaan limbah}

\section{a. Pengelolaan limbah padat}

Memiliki MoU antara RS dan pihak yang melakukan pemusnahan limbah dikarenakan incinerator tidak dapat digunakan (rusak), untuk tempat limbah padat kuat, tahan karat, kedap air, dengan penutup, dan kantong plastik, dengan warna dan lambang sesuai, tempat pengumpulan dan penampungan limbah sementara didesinfeksi setelah dikosongkan, diangkut ke TPS $>2$ kali/hari dan ke TPA 1 kali/hari, limbah domestic dibuang ke TPA yang ditetapkan PEMDA, sampah radoaktif ditangani sesuai peraturan yang berlaku, Sebaiknya kondisi ini tetap dipertahankan dan lebih ditingkatkan agar tetap dalam kondisi baik.

\section{b. Pengelolaan limbah cair}

RSUD Prof. Dr Margono Soekarjo Purwokerto untuk pengolahan limbah cair dilakukan pengolahan melalui instalasi pengolahan limbah, dan disalurkan melalui saluran tertutup, kedap air dan lancar, Sebaiknya kondisi ini tetap dipertahankan dan lebih ditingkatkan agar tetap dalam kondisi baik.

c. Kualitas effluent yang dibuang ke dalam lingkungan

Kualitas effluent yang dibuang ke dalam lingkungan telah memenuhi persyaratan Peraturan daerah provinsi jawa tengah No.5 Tahun 2012, Sebaiknya kondisi ini tetap dipertahankan dan lebih ditingkatkan agar tetap dalam kondisi baik.

\section{Tempat pencucian linen}

Terdapat keran air bersih dengan kapasitas, kualitas, kuantitas dan tekanan yang memadai serta disediakan keran air panas untuk desinfeksi awal, dilakukan pemilihan antara linen infeksius dan non infeksius, tersedia ruang pemisah antara barang bersih dan kotor, lokasi mudah dijangkau oleh kegiatan yang memerlukan dan jauh dari pasien serta tidak berada di jalan, lantai terbuat dari beton yang kuat, rata, tidak licin, dengan kemiringan 3\%, pencahayaan 216 lux dan terdapat sarana pengering untuk alat-alat sehabis dicuci, Sebaiknya kondisi ini tetap dipertahankan dan lebih ditingkatkan agar tetap dalam kondisi baik.

\section{Pengendalian serangga dan tikus}

a. Secara fisik : konstruksi bangunan, tempat penampungan air, penampungan sampah tidak memungkinkan sebagai tempat berkembang biaknya serangga dan tikus.

b. Secara kimia : insektisida yang dipakai memiliki toksisitas rendah terhadap manusia dan tidak bersifat persisten.

Namun untuk penampungan sampah dapat memungkinkan menjadi tempat berkembang biaknya serangga dan tikus karena tempat penampungan sampah sementara (domestic) dalam keadaan terbuka, sebaiknya tempat penampungan sampah sementara (domestic) diberi tutup dan dilakukan perbaikan bangunan pada tempat penampungan sampah.

8. Dekontaminasi melalui desinfeksi dan sterilisasi

Dekontaminasi melalui desinfeksi dan sterilisasi menggunakan peralatan sterilisasi uap (autoclave) gas dengan suhu $134^{\circ} \mathrm{C}$, alat dan perlengkapan medis yang sudah disterilkan atau didesinfeksi terlebih dahulu dibersihkan dari darah, jaringan tubuh, peralatan sterilisasi dikalibrasi satu tahun sekali, ruang operasi yang telah dipakai selalu didesinfeksi sebelum dilakukan operasi berikutnya, sebaiknya kondisi ini tetap dipertahankan dan lebih ditingkatkan agar tetap dalam kondisi baik

9. Pengamanan radiasi

Pengamanan radiasi memiliki izin mengoperasikan peralatan yang memancarkan radiasi, dosis radiasi pengion terhadap pekerja dan masyarakat tidak melebihi batas, memiliki sistem manajemen kesehatan dan keselamatan kerja pada pekerja dan masyarakat terhadap radiasi pengion, organisasi, peralatan proteksi radiasi, pemantauan dosis perorangan, instalasi dan gudang peralatan radiasi ditempatkan pada lokasi yang jauh dari tempat yang rawan kebakaran, tempat berkumpul orang banyak, sebaiknya dilakukan perbaikan bangunan pada dinding dan daun pintu dengan dilapisi timah hitam.

10. Penyuluhan kesehatan lingkungan

RSUD Prof. Dr. Margono Soekarjo Purwokerto dilakukan penyuluhan kesehatan secara langsung maupun tidak langsung kepada karyawan medis/non medis, pasien, pedagang makanan dalam lingkungan, dan pengunjung dengan cara dipasangi poster, peringatan, komunikasi dengan siaran, dilakukan pendidikan khusus, dan rapat khusus, hendaknya selalu mempertahankan dan lebih meningkatkan penyuluhan agar tetap baik.

11. Unit/instalasi sanitasi $R$

Unit/instalasi sanitasi RS dipimpin oleh tenaga teknis yang sudah mengikuti pelatihan sanitasi RS, Unit/instalasi sanitasi RS dipimpin oleh tenaga teknis yang sudah mengikuti pelatihan sanitasi RS. IPLRS, IPSRS, Instalasi 
Cuci Hama (Laundry) dan Instalasi Gizi dipimpin oleh tenaga teknis yang sudah megikuti pelatihan sanitasi maka unit atau instalasi yang berkaitan dengan sanitasi rumah sakit sudah memenuhi syarat pada Kepmekes RI No 1204/MENKES/SK/X/2004 Persyaratan Kesehatan Lingkungan Rumah Sakit, agar lebih produktif saat bekerja sebaiknya pemimpin yang sudah megikuti pelatihan sanitasi mengajarkan atau memberikan pelatihan kepada karyawan lain, sebaiknya pemimpin yang sudah mengikuti pelatihan sanitasi mengajarkan dan memberikan pelatihan kepada karyawan lain agar lebih baik.

\section{Penilaian Rumah Sakit}

RSUD Prof. Dr Margono Soekarjo Purwokerto mendapatkan nilai sebesar 9.326 dengan skor yaitu 93,2\% dan dapat dikatakan bahwa RSUD Prof. Dr Margono Soekarjo Purwokerto memenuhi persyaratan karena berdasarkan Kepmenkes RI Nomor 1204/MENKES/SK/X/2004 Tentang Persyaratan kesehatan lingkungan rumah sakit sekurang-kurangnya 75\% dari skor maksimal yang ada/yang diperiksa untuk Rumah Sakit Pemerintah Kelas B.

Berikut ini skore yang didapatkan dari hasil inspeksi sanitasi RSUD Prof. Dr Margono Soekarjo Purwokerto adalah :

Tabel 4.2 Penilaian Inspeksi Sanitasi RSUD Prof. Dr Margono Soekarjo Purwokerto Tahun 2016

\begin{tabular}{|c|c|c|c|c|c|c|c|c|c|c|}
\hline \multirow{2}{*}{$\begin{array}{l}\text { Type } \\
\text { kelas } \\
\text { RS }\end{array}$} & \multicolumn{10}{|c|}{$\begin{array}{l}\text { SKOR MINIMAL DARI MASING-MASING VARIAB } \\
\text { UPAYA (Dalam \%) }\end{array}$} \\
\hline & I & II & III & IV & $\mathrm{V}$ & VI & $\begin{array}{l}\text { VI } \\
\text { I }\end{array}$ & $\begin{array}{l}\text { VI } \\
\text { II }\end{array}$ & IX & $\mathrm{X}$ \\
\hline B & & & & & & & & & & \\
\hline $\begin{array}{l}\text { Stand } \\
\text { ar }\end{array}$ & 75 & 75 & 90 & 80 & 80 & 55 & 80 & 70 & 100 & 60 \\
\hline $\begin{array}{l}\text { Hasil } \\
\text { yang } \\
\text { didap } \\
\text { atkan }\end{array}$ & $\begin{array}{l}96, \\
8\end{array}$ & $\begin{array}{l}88 \\
4\end{array}$ & $\begin{array}{l}90, \\
7\end{array}$ & $\begin{array}{l}88 \\
, 1\end{array}$ & $\begin{array}{l}84 \\
, 4\end{array}$ & $\begin{array}{l}10 \\
0\end{array}$ & 80 & $\begin{array}{l}10 \\
0\end{array}$ & 75 & $\begin{array}{l}10 \\
0\end{array}$ \\
\hline
\end{tabular}

Keterangan :

Variabel I : Kesehatan Ligkungan Rumah Sakit

Variabel II : Penyehatan ruang dan bangunan

Variabel III : Penyehatan makanan dan minuman

Variabel IV : Penyehatan air

Variabel V : Pengelolaan limbah

Variabel VI : Tempat pencucian linen

Variabel VII : Pengendalian serangga dan tikus

Variabel VIII : Dekontaminasi melalui desinfeksi dan sterilisasi

Variabel IX : Pengamanan radiasi

Variabel X : Penyuluhan kesehatan lingkungan rumah sakit

Variabel XI : Unit/Instalasi sanitasi RS

Dari 11 variabel yang ada, bahwa RSUD Prof. Dr Margono Soekarjo Purwokerto hanya 1 variabel yang tidak memenuhi persyaratan yaitu terdapat pada variabel IX tentang pengamanan radiasi dengan hasil skor $75 \%$ dan dinyatakan tidak memenuhi syarat dikarenakan dinding dan daun pintu di ruang radiologi tidak dilapisi dengan timah hitam dan standar menurut Kepmenkes RI Nomor 1204/MENKES/SK/X/2004 Tentang Persyaratan kesehatan lingkungan rumah sakit pada variabel IX harus mendapatkan skor yaitu 100\%.

\section{SARAN}

Untuk lebih meningkatkan sanitasi RSUD Prof. Dr Margono Soekarjo Purwokerto menjadi lebih baik, dengan ini penulis memberikan saran-saran sebagai berikut :

1. Perlu dilakukan pemantauan, pengawasan dan pelatihan mengenai pengamanan radiasi pada pekerja dan masyarakat dengan cara menggunakan alat pelindung diri seperti apron, penahan radiasi gorad, sarung tangan proteksi, penahan radiasi, masker, sarung tangan, kacamata timbal, pemantauan dosis radiasi dengan menggunakan TLD (Termo Luminescence Desimeter) atau film badge, pemeriksaan kesehatan pada petugas secara berkala sekurang-kurangnya 1 kali satu tahun, dilakukan pelatihan tentang keselamatan dan kesehatan kerja terhadap radiasi, lamanya kerja untuk pekerja paling lama 10 hari kerja, dan untuk pekerja umur yang tidak boleh $<18$ tahun dan pekerja wanita dalam masa menyusui tidak diizinkan bertugas karena resiko kontaminasi tinggi, untuk petugas dan pasien yang sering terpapar radiasi diharapkan mengonsumsi makanan dan minuman yang mengandung protein tinggi untuk memperbaiki sel-sel tubuh.

2. Melakukan perbaikan untuk permukaan antara dinding dan lantai dibuat membentuk konus/lengkung agar mudah dibersihkan pada saat pembersihan lantai.

4. Perlu adanya perbaikan di halaman taman dan tempat parkir sehingga pada musim hujan halaman taman dan tempat parkir tidak berdebu/becek sehingga tidak mengganggu semua orang yang berada di RS termasuk karyawan maupun pengunjung.

5. Perlu adanya penurunan intensitas cahaya di ruang perawatan dengan mengurangi watt lampu yang ada di ruang perawatan sehingga tidak mengganggu pasien atau pengunjung yang diakibatkan karena cahaya yang terlalu terang.

6. Perlu adanya penurunan intensitas cahaya di meja operasi dengan mengurangi watt lampu yang ada di meja operasi.

7. Perlu adanya pengukuran intensitas suara di dalam maupun di luar gedung RSUD Prof. Dr Margono Soekarjo Purwokerto agar kondisi bagian dalam maupun luar tetap terkontrol dan terkendali.

8. Perlu dibuat ruang kedap suara atau diberi alat peredam suara agar intensitas suara di ruang 
perawatan tidak terlalu tinggi sehigga tidak mengganggu pasien.

9. Perlu dilakukan perbaikan bangunan di tempat penampungan sampah sementara (domestic) dan memberikan penutup menggunakan papan agar tidak menjadi tempat perkembangbiakan serangga dan tikus.

10. Mempertahankan kualitas yang sudah memenuhi syarat atau lebih meningkatkan lagi sehingga kondisi kesehatan lingkungan rumah sakit lebih baik.

\section{DAFTAR PUSTAKA}

Bapedal, 1995, KepBappedal Nomor 03/Bapedal/09/1995 Tentang Baku Mutu Emisi Udara Incenerator, Jakarta

Darpito, 2003, Standar dan Prosedur Pengelolaan Limbah Medis Rumah Sakit, Jurnal Kesehatan Masyarakat Indonesia.

Departemen Kesehatan RI, 1992, Standar Pelayanan Kesehatan Rumah Sakit, Jakarta : Depkes RI.

Depkes RI, 1988, Pedoman Sanitasi Rumah Sakit di Indonesia, Jakarta

Depkes RI, 2009, Undang-undang Republik Indonesia Nomor 36 Tahun 2009 Tentang Kesehatan, Jakarta : Depkes RI.

Depkes RI, 2009, Undang-undang Republik Indonesia Nomor 44 Tahun 2009 Tentang Rumah Sakit, Jakarta

KARS, 2012, Komisi Akreditasi Rumah Sakit, Jakarta

Kepmenkes RI, 2004, Keputusan Menteri Kesehatan Republik Indonesia Nomor 1204/MENKES/SK/X/2004 Tentang Persyaratan Kesehatan Lingkungan Rumah Sakit, Jakarta

Kepmenkes RI, 2007, Keputusan Menteri Kesehatan Republik Indonesia Nomor 432/MENKES/SK/V/2007 Tentang Pedoman Manajemen Kesehatan dan Keselamatan Kerja di Rumah Sakit, Jakarta
Peraturan Daerah Provinsi Jawa Tengah Nomor 5 Tahun 2012 Tentang Perubahan Atas Peraturan Daerah Provinsi Jawa Tengah Nomor 10 Tahun 2004 Tentang Baku Mutu Air Limbah, Jawa Tengah.

Peraturan Pemerintah RI, Peraturan Pemerintah Republik Indonesia Nomor 66 Tahun 2014 Tentang Kesehatan Lingkungan, Jakarta

Permenkes RI, 1990, Peraturan Menteri Kesehatan Republik Indonesia Nomor 416/MENKES/PER/IX/1990 Tentang Syaratsyarat dan Pengawasan Kualitas Air, Jakarta

Permenkes RI, 2010, Peraturan Menteri Kesehatan Republik Indonesia Nomor 340/MENKES/PER/III/2010 Tentang Klasifikasi Rumah Sakit, Jakarta

Permenkes RI, 2010, Peraturan Menteri Kesehatan Republik Indonesia Nomor 492/MENKES/PER/IV/2010 Tentang Persyaratan Kualitas Air Minum, Jakarta

Permenkes RI, 2011, Peraturan Menteri Kesehatan Republik Indonesia Nomor 1096/MENKES/PER/VI/2011 Tentang Hygiene Sanitasi Jasaboga, Jakarta

Risnawati, 2015, Studi Sanitasi RSUD Labuang Baji Makassar dan RS Islam Faisal Makassar, Jurnal Kesehatan Mayarakat.

Syaiful Syadir, 2015, Studi Sanitasi Rumah Sakit Ibnu Sina Makassar dan Rumah Sakit Pelamonia Makassar, Jurnal Kesehatan Mayarakat.

Suyatno Sastrowinoto, 1985, Kebutuhan Rentang Suhu Nyaman Bagi Setiap Orang, Jakarta

Tahir Abdul, 2011, Lingkungan Fisik dan Angka Kuman Udara di Ruangan Rumah Sakit Umum Haji Makassar, Sulawesi Selatan, Jurnal Kesehatan Mayarakat. 